\title{
Senaste nytt i institutionens skriftserier
}

Skriftserien Scripta Minora startade 1989 och innehåller uppsatser och rapporter författade av studenter och lärare vid institutionen. En förteckning över samtliga nummer finns på adressen http://www.vxu.se/hum/publ/scriptaminora/. Numera är serien reserverad för C- och D-uppsatser av hög kvalitet. Uppsatser och rapporter författade av forskare och lärare publiceras i Rapporter från Växjö universitet, Humaniora.

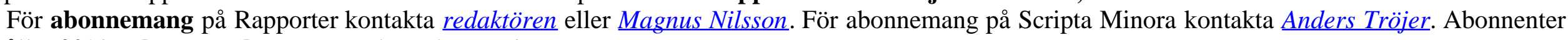
erhåller $\mathbf{2 0 \%}$ rabatt. För lösnummer kontakta Anders Tröjer.

Rapporter från Växjö universitet, Humaniora. Nr 62000.

Spader Dame. Texter till minne av Anne Marie Wieselgren. ISBN 91-7636-247-7.

Anne Marie Wieselgren var lärare i Nordiska språk vid f.d. Högskolan i Växjö. Hon avled 1998. Spader Dame är skriven till hennes minne. Boken innehåller 21 texter som alla har anknytning till hennes yrke och intressesfär: syntaktiska problem, översättnings- och interferensproblem mellan svenska och andra språk. Här diskuteras språket i gymnasisters uppsatser och hur chefer och deras medarbetare samspelar i utvecklingssamtal.

En text tar itu med korsordsspråkets klurigheter, andra fördjupar sig i författare såsom Simone de Beauvoir, Sigrid Undset, Vilhelm Moberg. Vidare ges en exposé över Mariabilder i svensk lyrik och vampyrernas roll i den västliga civilisationen.

Mat är ämnet för tre artiklar. Var Bellman verkligen en matpoet? Hur såg Mannerheims matpreferenser ut? Vad har vi ätit i kristider? Ett bidrag dryftar det litterära värdet av linear B, ett grekiskt skriftfynd. De fem minnesteckningarna i slutet av Spader Dame belyser Anne Marie Wieselgrens personlighet ur skiftande synvinklar.

Det är vår förhoppning att läsningen i denna bok ska bereda nöje, ge kunskap och - för dem som kände Anne Marie Wieselgren - väcka minnen.
Snart utkommer i Rapportserien:

Peter Danielsson: Från gård till slagfält.

Från gård till slagfält riktar sitt fokus mot det äldre militära indelningsverket, dvs föregångaren till Karl XI:s mer välkända militära resurs- och underhållssystem. Fil.lic. Peter Danielsson skapar här en bild av hur detta äldre indelningsverk fungerade från 1640-talet och fram till den tidsperiod då det omformades drygt fyrtio år senare. Tidigare forskning har i regel avfärdat detta äldre system som en ofullgången föregångare till det senare, oftast utan att kunna bygga på några djupare undersökningar av hur systemet faktiskt fungerade. Från gård till slagfält försöker i någon mån råda bot på denna brist och dessutom avliva en del myter. Med hjälp av en djupundersökning av förhållandena i Aspelands härad i Kalmar län ställer författaren en rad generella och samtidigt konkreta frågor, bland annat beträffande hur väl upphovsmännens intentioner uppfylldes i praktiken, hur systemets normativa strukturer var utformade och huruvida det fanns någon kontinuitet från det äldre militära indelningsverket till det yngre. 